ZOOLOGIA 31 (5): 426-434, October, 2014

http://dx.doi.org/10.1590/S1984-46702014005000001

\title{
Effects of spatial and environmental factors on benthic a macroinvertebrate community
}

\author{
Renan S. Rezende ${ }^{1,2,3}$, Anderson M. Santos ${ }^{1}$, Carlos Henke-Oliveira ${ }^{2}$ \& José F. Gonçalves Jr1,2 \\ 'Programa de Pós-Graduação em Ciências Biológicas, Departamento de Biologia Geral, Instituto de Ciências Biológicas, \\ Universidade Estadual de Montes Claros. Caixa Postal 126, 39401-089 Montes Claros, MG, Brazil. \\ E-mail: anderson.santos@unimontes.br \\ ${ }^{2}$ Departamento de Ecologia, Instituto de Ciências Biológicas, Universidade de Brasília. 70910-900 Brasília, DF, Brazil. \\ E-mail: carloshenke@unb.br; jfjunior@unb.br \\ ${ }^{3}$ Corresponding author. E-mail: renanrezende30@gmail.com
}

\begin{abstract}
Interactions between terrestrial and aquatic systems influence the structure of river habitats and, consequently, affect their benthic macroinvertebrate composition. The aim of this study was to evaluate the effects of spatial and environmental variables (local physical and chemical variables of water and regional landscape characteristics) on the benthic macroinvertebrate community of the Pandeiros River Basin. Biotic and abiotic variables were evaluated at 20 sampling sites distributed across the primary sub-basins of the Pandeiros River Basin. We found that the macroinvertebrates were primarily affected by environmental variables. The most important environmental variables were pebble proportion and water conductivity at the local scale (7.2\% of explained variation) and elevation and nonforest areas at the regional scale (6.9\% of explained variation). The spatial variables were representative only in shared explained variation with the environmental matrices (local-spatial $=0.2 \%$ and regional-spatial $=2 \%$; all matrices combined $=4.4 \%$ ). Sampling sites with higher non-forest areas, lower elevations, and steeper slopes presented low pebble fractions and higher electrical conductivities. Habitat diversity was lower when the percentage of pebbles decreased, resulting in decreased taxonomic richness and diversity in macroinvertebrate communities. High electrical conductivities and non-forest areas also had negative effects on macroinvertebrate density due to the loss of habitat diversity. We conclude that higher proportions of pebbles in the substrate and higher altitudes were likely the primary variables for positive effects on the taxonomic richness and density of macroinvertebrate communities.
\end{abstract}

KEY WORDS. Elevation; metacommunity; non-forest areas; pebbles.

Watersheds are one of the major landscape units affected by human activities (e.g., agriculture, industry, urbanization) and by natural events (e.g., native forest succession), and these activities are the key determinants of watershed quality (NESSIMIAN et al. 2008). In addition to natural variations (e.g., upstreamdownstream gradients) in the aquatic environment (VANNOTE et al. 1980), understanding the effects of land use is important for predicting changes in the physical, chemical, and biological health of ecosystems (GARDINER et al. 2009). Different land uses (e.g., agriculture, industry, and urbanization) may generate physical changes in the habitat (РARK et al. 2011), which alter the diversity and function of the ecosystem. Thus, when trying to understand the processes affecting stream biodiversity, the regional landscape should be considered (Tupinambas et al. 2007).

To assess local environmental conditions, the composition and diversity of the physical environment must be considered (Beisel et al. 1998). According to Harper et al. (1997), substrate composition (e.g., pebbles, gravel, and stones), detritus input, and canopy cover are three of the primary variables that control biodiversity in lotic macroinvertebrate communities. Natural topographical characteristics may also decrease macroinvertebrate diversity if fine sedimentary particles are predominant in the substrate (VANNOTE et al. 1980). The physical and chemical characteristics of the water (e.g., dissolved oxygen, conductivity, alkalinity, and temperature) may also influence aquatic life by altering the environment and the community composition (Allan 2007, Melo 2009). Therefore, environmental characteristics are critical for understanding the distribution and diversity of the macroinvertebrate communities in aquatic systems (Costa \& Melo 2007, Melo 2009).

Benthic macroinvertebrate communities are central components of freshwater ecosystems (VANNOTE et al. 1980, ALLAN 2007) and are perhaps the most widely used biological indicators of aquatic health (e.g., Tupinambas et al. 2007, Moreno et al. 2009, Ferreira et al. 2011). Previous studies have attempted to clarify the relationship between local (ONODA et al. 2009) and regional habitat conditions (ALLAN 2007, Jun et al. 2011, PARK et al. 2011) because these relationships affect the structure of 
benthic macroinvertebrate communities. These studies have generally been performed in temperate systems and have primarily focused on the importance of local environmental conditions. Some studies have examined the effects of local (physical and chemical variables of water) and regional (land use and landscape characteristics) habitat conditions on benthic macroinvertebrate communities in tropical regions (BOYERo \& Bailey 2001, Costa \& Melo 2007, BüCKer et al. 2010). However, few studies have also investigated the influence of spatial processes on community structure (SIQUeIra et al. 2012).

Ecological theory predicts that different processes act as filters on communities at local and regional scales, and the metacommunity framework can be useful for studying these structuring processes (Leibold et al. 2004, CotTenie 2005, Siqueira et al. 2012). A metacommunity can be defined as a set of local communities linked by the dispersal of multiple potentially interacting species (Leibold et al. 2004), and metacommunities are structured by both environmental and spatial processes (HoLYOAK et al. 2005). The metacommunity framework suggests that local communities are controlled by neutral processes, species sorting, patch dynamics and mass effects, depending on the relative influences of environmental and spatial processes on community structure (Leibold et al. 2004, Siqueira et al. 2012).

According to Siqueira et al. (2012), the community controls mentioned above can act simultaneously and should not be viewed as independent processes but rather as points along a continuum. The neutral model (driven primarily by stochastic processes and resulting in strong spatial structures) and species sorting (based on niche theory) represent the endpoints of a continuum of processes acting on communities; patch dynamics and mass effects combine both perspectives (for details, see Hubbell 2001, Leibold et al. 2004, Cottenie 2005, HolyoaK et al. 2005, Siqueira et al. 2012). Therefore, one could hypothesize that some communities are conforming to environmental processes and that other communities are more influenced by spatial processes (Leibold et al. 2004, Holyoak et al. 2005, Siqueira et al. 2012).

Our goal was to evaluate the effects of spatial and environmental variables (local physical and chemical variables of water and regional landscape characteristics) on the benthic macroinvertebrate community in the Pandeiros River Basin, Brazil. Specifically, we addressed the following questions: 1) What are the relative importances of spatial and environmental variables (local and regional scale) on the richness and density of this benthic macroinvertebrate community? 2) Which environmental variables are the most important for structuring this benthic macroinvertebrate community?

\section{MATERIAL AND METHODS}

The present study was performed in the Pandeiros River Basin, state of Minas Gerais, southeastern Brazil (Figs 1 and 2). This river basin, which occupies $3,800 \mathrm{~km}^{2}$, is populated by a small ca. 8,164 inhabitants, who are distributed in small, rural

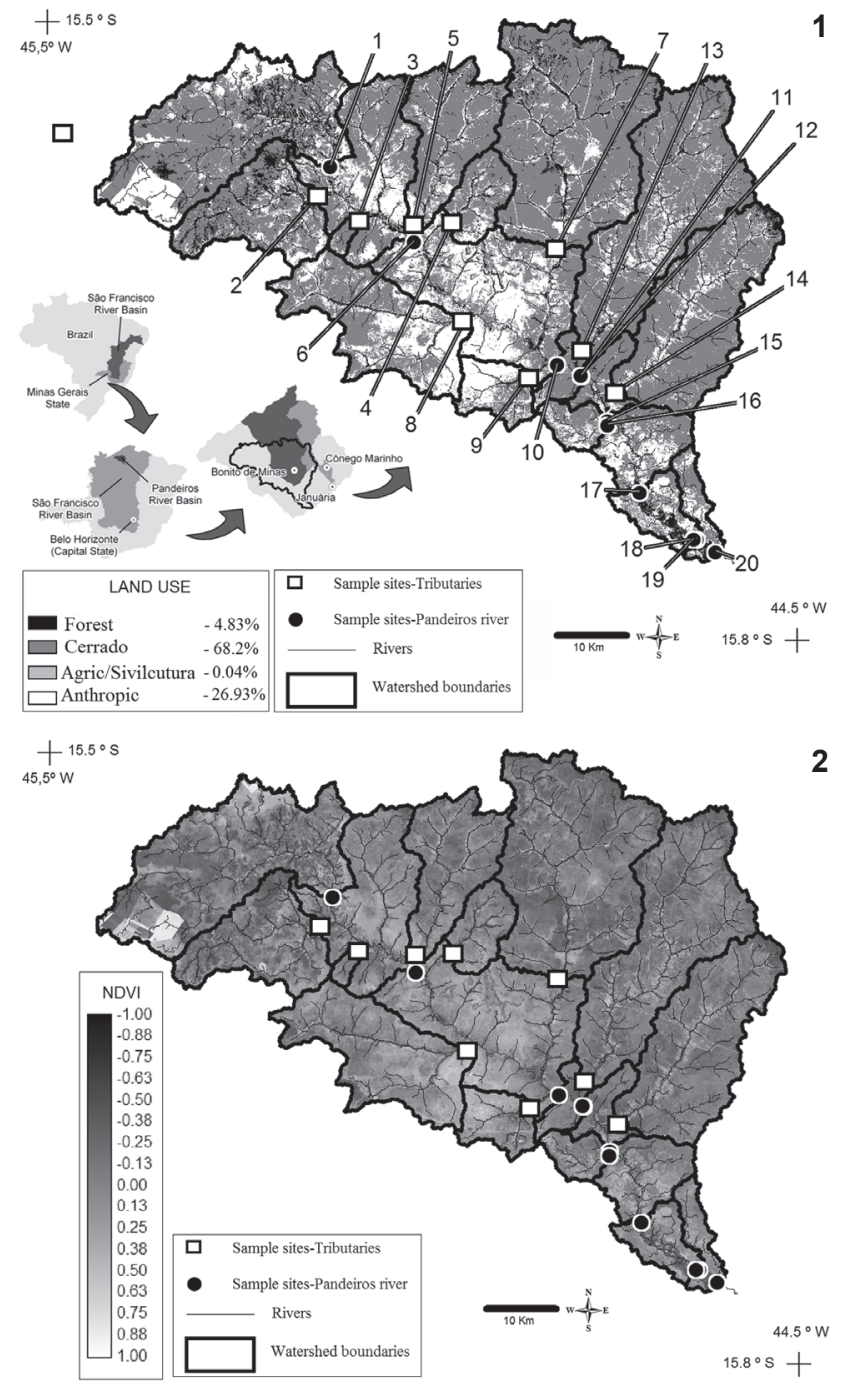

Figures 1-2. Sampling sites and sub-basins within the Pandeiros River Basin drainage, showing their geographical location within Brazil and Minas Gerais State and the distributions of land use (1) and NDVI values (2) in the study area.

communities, and subsist on small-scale agriculture and livestock farming. The climate of this region is predominantly semiarid, with temperatures varying from 18 to $35^{\circ} \mathrm{C}$. The altitude ranges from 600 to $780 \mathrm{~m}$, and the soils are predominantly red oxisols (latosols) with a sandy texture and quartz sand. Based on historical data, the average discharge of the primary river is $8 \mathrm{~m}^{3} / \mathrm{s}$ during the dry season and $24 \mathrm{~m}^{3} / \mathrm{s}$ during the rainy season. The Pandeiros River, which is the primary water body in the basin, is approximately $145 \mathrm{~km}$ long. The sampling sites represent 20 river reaches, with 11 sites on the Pandeiros River and 9 sites on its primary tributaries (Figs 1 and 2). We sampled each site four times in 2008: February, May, September, and 
November. The sampling sites were selected based on their geographical locations within the hydrographic basin, as represented by the Otto Pfafstetter coding system-coded basin areas designated by the National Water Agency of Brazil (Agência Nacional de Águas - ANA, Appendix S1*).

Landscape analysis was performed using a geographical information system (GIS) based on a recent (2010) multispectral Landsat 5 Thematic Mapper (TM) image. The image was classified into cerrado (Brazilian savanna), forest, agriculture/ silviculture, and non-forest areas (primarily characterized by roads). Land use was determined using a maximum-likelihood classification algorithm. The normalized difference vegetation index (NDVI) was used as an additional investigative tool due to its potential to detect anthropogenic or natural changes in vegetation (Rouse et al. 1973) (Fig. 2). The index ranges from 1 to +1 , with positive values indicating more dense vegetation (Dennison et al. 2009). Vegetation indices can be used to measure the changes in leaf area (i.e., canopy openness) that result from defoliation (DENNison et al. 2009). The NDVI (Rouse et al. 1973 ) is calculated as follows: NDVI $=\rho \mathrm{NIR}-\rho$ red $/ \rho \mathrm{NIR}+\rho$ red, where $\rho$ NIR and ñred are the reflectances of the near-infrared bands and the red band, respectively.

Elevation data supplied by the National Aeronautics and Space Administration Shuttle Radar Topography Mission (NASA/SRTM) project were used to extract the primary topographical features, including the elevation, slope, and drainage network. The georeferenced database was structured to provide secondary topographical information related to the drainage areas of individual sampling sites, including the watershed surface, sinuosity index, and slope (Figs 1 and 2).

Three sediment samples were collected from each sampling site using a plastic container to determine the granulometric composition and organic matter content of the sediment. The granulometric composition of the sediment was determined according to the methodology proposed by SuguIo (1973) and modified by Callisto \& Esteves (1996). Ten stones were collected randomly at each sampling point in the field, and their volumes were estimated using a caliper to measure their heights, widths, and thicknesses. The sediment organic matter was estimated according to the method of SugUIO (1973) by incinerating three 0.3 g aliquots for 4 hours at $550^{\circ} \mathrm{C}$. A multi-analyzer (Model 85, YSI Incorporated, Yellow Springs, OH, USA) was used to record the following water-column parameters in situ: temperature, electrical conductivity, and dissolved oxygen. The total alkalinity was determined by Gran plots as described by Carmouze (1994). The riparian-vegetation canopy openness was quantified using hemispheric photographs (taken with a Nikon FCE9 fisheye lens (Nikon Corp, Tokyo, Japan) and analyzed using the Gap Light Analyzer 2.0 software (Simon Fraser University, Burnaby, BC, Canada).

To examine the benthic community (Appendix S2*), three sample units were collected to represent the different microhabitats at each sampling site using a Surber stream-bottom sampler with a sampling area of $1024 \mathrm{~cm}^{2}$ and a mesh size of $0.250 \mathrm{~mm}$ (Pérez 1988). The collected material was washed on $0.50 \mathrm{~mm}$ sieves and screened using a stereomicroscope. Then, the aquatic macroinvertebrates were collected and identified (to the family level) using available and appropriate taxonomic keys (Pérez 1988, Merrit \& Cummins 1996, Cummins et al. 2005). Based on this inventory of the benthic macroinvertebrate communities, the average family richness and density were calculated for each sampling site. This methodology has yielded good results in studies of the São Francisco River Basin (Moreno et al. 2009, Ferreira et al. 2011).

The importances of spatial (geographical coordinates) and environmental variables (local physical and chemical parameters of water and regional landscape variables) on the structure of benthic macroinvertebrate communities were evaluated by a partial redundancy analysis (pRDA). The local physical parameters used were granulometric fractions (silt + clay, very fine sand, fine sand, medium sand, coarse sand, very coarse sand, gravel, pebbles, and stones), the percentage of organic matter, and the percentage of canopy openness. The chemical parameters of water used were dissolved oxygen, electrical conductivity, water temperature, and alkalinity. The regional landscape variables used were the average value of non-forest areas; drainage density; drainage form; sinuosity; average elevation; slope; percentage of forest, cerrado, agriculture/silviculture, and anthropic areas; and the NDVI at each of the sampling sites.

The geographical coordinates (latitude and longitude in Universal Transverse Mercator (UTM)) of each sampling site were used in a principal coordinates of neighbor matrices (PCNM) method described by BorCARd \& LEgENDRE (2002) and by DRAY et al. (2006). Next, redundancy analysis (RDA) was used to remove the effects of non-important variables on the spatial and environmental data matrix. One forward selection was made for each set of predictor variables (spatial, local, and regional landscape variables). A global test was also performed, including all explanatory variables and the $\mathrm{R}_{\text {adj }}^{2}$ (according to Ezekiel's correction: Peres-Neto et al. 2006), which was used as a second criterion (in addition to an alpha-value of 0.05 ) to select the variables to retain in the subsequent analyses.

The importance of environmental variables on the structure of the benthic macroinvertebrate communities was obtained in the RDA (forward model selection) by first selecting the explanatory variable that maximized the fit of the model and by computing an F-ratio and a p-value by permuting the residuals under the full model approach (BLANCHET et al. 2008). Whenever $\mathrm{p} \leqslant 0.05$ was obtained, then $\mathrm{R}^{2}$ adj was computed for the forward model selection. If $\mathrm{R}^{2}$ adj was smaller for the forward model-selection than for the global test, then another environmental variable was added to the analysis, and the permutation test was repeated (Blanchet et al. 2008). All of the

*Available as Online Supplementary Material accessed with the online version of the manuscript at http://www.scielo.br/zool 
analyses were performed using the average values of the environmental and biological variables measured during all of the sampling periods at each site. Analyses were performed in the $R$ environment ( $R$ Development Core Team 2013) using the vegan package (OKSANEN et al. 2013).

\section{RESULTS}

\section{Regional and local physical and chemical characteristics of the stream}

The drainage area of the sampling sites totaled 390,326 ha and was divided as follows: forest $(4.83 \%)$, cerrado (Brazilian savanna; 68.2\%), agriculture/silviculture (agroforestry; $0.04 \%)$, and anthropogenic areas (26.93\%). The latter category primarily consisted of unpaved roads and a small amount of urban area. The average NDVI value of the entire basin was 0.339 , indicating that the study area could be considered preserved (Table I). Regarding the granulometric composition, very fine sand was the most abundant fraction (average: $46 \pm 18 \%$ SD; range: 16 to $83 \%$ ), followed by pebbles (average: $20 \pm 19 \%$ SD; range: 0 to $33 \%$ ), fine sand (average: $12 \pm 8 \%$ SD; range: 2 to $32 \%$ ), and medium sand (average: $8 \pm 7 \%$ SD; range: 2 to $33 \%)$. The silt, clay, coarse sand, very coarse sand, gravel, and stone fractions showed low percentages throughout the river system $(<2 \%$; Table II). The sampling sites varied widely in oxygen saturation (average: $63 \pm 15 \% \mathrm{SD}$; range: 33 to $81 \%$ ), electrical conductivity (average: $80 \pm 56 \mu \mathrm{cm}^{-1} \mathrm{SD}$; range: 27 to $277 \mu \mathrm{S} \mathrm{cm}^{-1}$ ), and alkalinity (average: $655 \pm 577 \mu \mathrm{Eq} / \mathrm{L} \mathrm{SD}$; range: 130 to $1298 \mu \mathrm{Eq} / \mathrm{L})$. However, the water temperature was similar between sampling sites (average: $24 \pm 2^{\circ} \mathrm{C} \mathrm{SD}$; range: 20 to $26^{\circ} \mathrm{C}$; Table III).

\section{Variables structuring the benthic macroinvertebrate community}

The family richness (average: $9 \pm 3 \mathrm{SD}$; range: 2 to 15 ; accumulated: $28 \pm 5$ SD; range: 13 to 38 ) and density (average: $125 \pm 85 \mathrm{ind} / \mathrm{m}^{2} \mathrm{SD}$; range: 14 to $332 \mathrm{ind} / \mathrm{m}^{2}$ ) of macroinvertebrate communities varied widely in the sampling sites (Table IV). The family richness and density values of macroinvertebrate communities were higher in tributary streams (richness average: $11 \pm 2$ SD; richness accumulated: $30 \pm 4$ SD; density average: $181 \pm 86 \mathrm{ind} / \mathrm{m}^{2} \mathrm{SD}$ ) compared with the Pandeiros River (richness average: $6 \pm 3 \mathrm{SD}$; richness accumulated: $25 \pm 5 \mathrm{SD}$; density average: $78 \pm 51 \mathrm{ind} / \mathrm{m}^{2} \mathrm{SD}$ ).

The pRDA indicated that the local physical and chemical matrix explained $7.2 \%$ of the total faunal variation (adjusted $\left.\mathrm{R}^{2} ; \mathrm{p}<0.001\right)$, whereas the regional landscape matrix explained $6.9 \%$ of the total faunal variation (adjusted $\mathrm{R}^{2} ; \mathrm{p}<0.001$ ); thus, $14.1 \%$ of the total faunal variation was explained by the environmental matrices. The shared variation between the local and regional environmental variables was near zero, indicating that their effects were independent of each other. The spatial matrix

Table I. Average values for non-forest areas (A/ha), drainage density (DD), drainage form (F), sinuosity (S), average elevation (AE), slope $(\mathrm{SI})$, percentage of forest $(\% \mathrm{~F})$, cerrado $(\% \mathrm{C})$, agriculture/silviculture $(\% \mathrm{~A} / \mathrm{F})$, anthropic areas $(\% \mathrm{~A})$, and NDVI at each of the sampling sites along the Pandeiros River Basin.

\begin{tabular}{|c|c|c|c|c|c|c|c|c|c|c|c|}
\hline Sites & $\mathrm{A} / \mathrm{ha}$ & DD & $\mathrm{F}$ & $S$ & $\mathrm{AE}$ & SI & $\% \mathrm{~F}$ & $\%$ C & $\% \mathrm{~A} / \mathrm{S}$ & $\% \mathrm{~A}$ & NDVI \\
\hline P1 & 49,146 & 5.466 & 2.224 & 1.266 & 780.0 & 4.918 & 7.774 & 63.646 & 0.000 & 28.580 & 0.336 \\
\hline P2 & 22,475 & 5.249 & 1.876 & 1.249 & 714.6 & 6.636 & 11.528 & 70.083 & 0.002 & 18.387 & 0.369 \\
\hline P3 & 1,446 & 4.949 & 1.463 & 1.188 & 666.0 & 4.339 & 0.831 & 88.474 & 0.000 & 10.695 & 0.348 \\
\hline P4 & 8,630 & 4.845 & 1.484 & 1.179 & 672.3 & 4.617 & 3.213 & 70.419 & 0.000 & 26.367 & 0.328 \\
\hline P5 & 21,517 & 4.654 & 1.877 & 1.223 & 692.9 & 4.826 & 4.821 & 75.791 & 0.000 & 19.388 & 0.352 \\
\hline P7 & 57,049 & 4.970 & 1.795 & 1.184 & 715.8 & 4.481 & 5.239 & 82.171 & 0.253 & 12.336 & 0.379 \\
\hline P8 & 30,191 & 4.752 & 1.996 & 1.239 & 630.6 & 3.130 & 1.271 & 0.000 & 54.699 & 44.030 & 0.296 \\
\hline P9 & 8,123 & 4.806 & 1.588 & 1.172 & 606.7 & 3.729 & 1.802 & 0.000 & 35.914 & 62.284 & 0.264 \\
\hline P10 & 266,470 & 5.066 & 2.238 & 1.224 & 691.0 & 4.674 & 5.236 & 64.589 & 0.054 & 30.121 & 0.334 \\
\hline P11 & 318,462 & 5.080 & 2.214 & 1.215 & 690.2 & 4.580 & 4.817 & 67.428 & 0.046 & 27.710 & 0.338 \\
\hline P12 & 318,454 & 5.080 & 2.214 & 1.215 & 690.2 & 4.580 & 4.817 & 67.428 & 0.046 & 27.710 & 0.338 \\
\hline P13 & 47,661 & 5.072 & 2.063 & 1.170 & 696.9 & 4.163 & 2.615 & 81.832 & 0.001 & 15.552 & 0.362 \\
\hline P14 & 37,797 & 5.069 & 1.846 & 1.175 & 640.5 & 3.922 & 2.885 & 83.148 & 0.001 & 13.966 & 0.361 \\
\hline P15 & 362,089 & 5.086 & 2.176 & 1.210 & 682.8 & 4.495 & 4.603 & 69.284 & 0.040 & 26.072 & 0.341 \\
\hline P16 & 367,109 & 5.087 & 2.181 & 1.210 & 681.0 & 4.503 & 4.560 & 69.203 & 0.040 & 26.198 & 0.341 \\
\hline P17 & 378,930 & 5.103 & 2.207 & 1.212 & 676.3 & 4.488 & 4.523 & 68.871 & 0.039 & 26.567 & 0.340 \\
\hline P18 & 386,618 & 5.133 & 2.340 & 1.215 & 672.4 & 4.451 & 4.754 & 68.376 & 0.038 & 26.832 & 0.340 \\
\hline P19 & 386,519 & 5.132 & 2.334 & 1.215 & 672.4 & 4.451 & 4.743 & 68.389 & 0.038 & 26.830 & 0.340 \\
\hline P20 & 392,017 & 5.149 & 2.341 & 1.218 & 669.9 & 4.426 & 4.832 & 68.197 & 0.037 & 26.933 & 0.339 \\
\hline
\end{tabular}


Table II. Average values and standard deviations of the sediment variables evaluated in 20 sites along the Pandeiros River Basin. Granulometric fractions were silt + clay $(S+C)$, very fine sand (VFS), fine sand (FS), medium sand (MS), coarse sand (CS), very coarse sand $(V C S)$, gravel $(G)$, pebbles $(P)$, stones per cubic meter $(S)$, and the percentage of organic matter (\% OM).

\begin{tabular}{|c|c|c|c|c|c|c|c|c|c|c|}
\hline ites & $+\mathrm{C}$ & VFS & FS & MS & CS & VCS & G & $P$ & $S$ & OM \\
\hline P1 & 55 & $.26=$ & $84 \pm$ & 93 & $19 \pm$ & $78 \pm 0.18$ & $.94 \pm 2.55$ & $64.48 \pm 15.50$ & $0.029 \pm 0.001$ & $2.28 \pm 0.71$ \\
\hline P2 & $2 \pm 0.89$ & $.04 \pm$ & 11.65 & 52 & 46 & 62 & $13.56 \pm 21.06$ & $60 \pm 25.46$ & $3 \pm 0$ & 1.47 \\
\hline P3 & $57 \pm 0.65$ & $.88 \pm 30.97$ & $28.37 \pm 14.68$ & $25.62 \pm 20.77$ & $4.89 \pm 7.90$ & $0.66 \pm 0.44$ & $0.00 \pm 0.00$ & - & - & $0.50 \pm 0.41$ \\
\hline P4 & $21 \pm$ & $7.40 \pm 17.32$ & $8.37 \pm 7.48$ & $6.51 \pm 9.36$ & 0.79 & .28 & $3.55=$ & 4 & 4 & $1.59 \pm 0.99$ \\
\hline P5 & $0 \pm 1.25$ & $43.39 \pm 32.37$ & $9.01 \pm$ & $1.86 \pm$ & $0.71 \pm$ & $0.22 \pm 0.31$ & $2.18 \pm$ & $41.64 \pm 28.49$ & $0.049 \pm 0$ & 0.80 \\
\hline P6 & 36 & $76.70 \pm$ & 15.0 & \pm & $0.29 \pm$ & 22 & - & - & - & .07 \\
\hline P7 & 6 & 86 & $8.66 \pm 8.65$ & $2.58 \pm 2.2$ & 4 & 86 & 8 & 1 & 3 & 53 \\
\hline P8 & 22 & $3.30 \pm$ & $28.17 \pm$ & - & 61 & 21 & $0.00 \pm 0.52$ & $0.00 \pm$ & - & 2. \\
\hline P9 & 02 & 20.001 & 0.07 & $0.10-2$ & & 62 & $14.4 \pm 14.33$ & $38.07 \pm 16.82$ & - & \\
\hline 10 & & 3 & & & & & & & & \\
\hline $\mathrm{P} 1$ & & 0 & 8 & & 6 & & & & & \\
\hline P12 & & $2.38 \pm 26.04$ & 等 & & & & & $17.43 \pm 19.21$ & $0.033 \pm 0$ & \\
\hline P13 & 34 & $35.42 \pm$ & 21.53 & 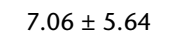 & 0.6 & $0.63 \pm 0.38$ & $3.01 \pm 2.08$ & 0 & 9 & \\
\hline P14 & 01 & $60.78 \pm$ & 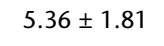 & 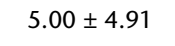 & 6.31 & 7.87 & $10.57 \pm$ & 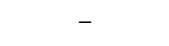 & 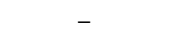 & 1. \\
\hline P15 & 2.26 & $47.10 \pm$ & $8.58 \pm 4.44$ & $2.04 \pm 1.90$ & 1.87 & 03 & $0.88 \pm 1.75$ & $35.46 \pm 8.79$ & $37+c-6$ & .03 \\
\hline P16 & $1.42 \pm$ & $51.90 \pm 38.05$ & $29.58 \pm 32.21$ & $12.19 \pm 11.78$ & 1.69 & .09 & $1.57 \pm 3.15$ & - & - & .77 \\
\hline P17 & $1.89 \pm$ & $66.60 \pm 38.80$ & $8.33 \pm 9.63$ & $11.65 \pm 14.79$ & 0.23 & .03 & - & $11.28 \pm 22.57$ & - & 85 \\
\hline P18 & $15.26 \pm 17.63$ & \pm 15.62 & $10.4 \pm 5.09$ & $20.94 \pm 8.87$ & $22.92 \pm 17.87$ & $7.47=$ & - & - & - & 31.47 \\
\hline P19 & $1.71 \pm 1.06$ & $83.94 \pm 21.02$ & $2.02 \pm 1.76$ & $1.69 \pm 1.80$ & $1.79 \pm$ & $2.48 \pm 2.88$ & $6.37 \pm 12$ & - & - & 0.91 \\
\hline P20 & $2.27 \pm 1.84$ & $55.86 \pm 42.40$ & $15.55 \pm 23.71$ & $25.45 \pm 33.46$ & $0.64 \pm 0.79$ & $0.24 \pm 0.47$ & - & - & - & $1.05 \pm 0.76$ \\
\hline
\end{tabular}

Table III. Average values and the standard deviation of the percentage of dissolved oxygen in the water $\left(\mathrm{O}_{2} \% \mathrm{St}\right)$, electrical conductivity $\left(\mu \mathrm{S} / \mathrm{cm}^{2}\right)$, water temperature (Temp), alkalinity ( $\mu \mathrm{Eq} / \mathrm{L})$, and the percentage of canopy openness (\% CO) in 20 sites along the Pandeiros River Basin.

\begin{tabular}{|c|c|c|c|c|c|}
\hline Sites & $\mathrm{O}_{2} \% \mathrm{St}$ & Conductivity & $\operatorname{Temp}\left({ }^{\circ} \mathrm{C}\right)$ & Alkalinity & $\% \mathrm{CO}$ \\
\hline P1 & $73.33 \pm 24.82$ & $65.28 \pm 5.02$ & $24.13 \pm 1.21$ & $394.90 \pm 253.61$ & 68.04 \\
\hline P2 & $79.90 \pm 4.35$ & $181.63 \pm 17.14$ & $23.13 \pm 0.95$ & $756.53 \pm 513.93$ & 5.28 \\
\hline P3 & $63.38 \pm 20.91$ & $64.08 \pm 0.61$ & $26.78 \pm 0.10$ & $236.15 \pm 184.30$ & 33.35 \\
\hline P4 & $73.43 \pm 13.39$ & $93.25 \pm 57.37$ & $21.40 \pm 2.04$ & $204.24 \pm 295.62$ & 9.48 \\
\hline P5 & $69.63 \pm 18.50$ & $41.63 \pm 22.74$ & $22.53 \pm 2.41$ & $179.48 \pm 136.57$ & 21.14 \\
\hline P6 & $66.45 \pm 25.23$ & $76.00 \pm 7.29$ & $25.03 \pm 1.01$ & $458.03 \pm 206.43$ & 16.13 \\
\hline P7 & $67.38 \pm 26.64$ & $37.75 \pm 49.62$ & $21.85 \pm 1.87$ & $734.22 \pm 915.14$ & 90.45 \\
\hline P8 & $39.58 \pm 26.88$ & $27.05 \pm 19.50$ & $24.83 \pm 1.58$ & $164.29 \pm 295.20$ & 54.64 \\
\hline P9 & $40.33 \pm 3.90$ & $28.30 \pm 37.81$ & $23.28 \pm 1.94$ & $130.19 \pm 186.11$ & 54.86 \\
\hline P10 & $71.93 \pm 24.86$ & $60.13 \pm 1.89$ & $23.70 \pm 1.44$ & $468.55 \pm 196.75$ & 16.13 \\
\hline P11 & $73.48 \pm 23.10$ & $60.17 \pm 1.88$ & $23.30 \pm 1.41$ & $373.76 \pm 214.67$ & 92.85 \\
\hline P12 & $73.48 \pm 25.31$ & $60.13 \pm 2.63$ & $23.25 \pm 1.67$ & $493.83 \pm 156.01$ & 22.46 \\
\hline P13 & $48.90 \pm 30.26$ & $77.27 \pm 17.81$ & $19.80 \pm 2.21$ & $526.20 \pm 361.75$ & 85.67 \\
\hline P14 & $33.99 \pm 24.87$ & $277.43 \pm 5.55$ & $21.80 \pm 1.51$ & $2590.33 \pm 1340.11$ & 37.99 \\
\hline P15 & $70.35 \pm 29.13$ & $104.73 \pm 5.16$ & $25.58 \pm 0.07$ & $1178.18 \pm 219.20$ & 85.38 \\
\hline P16 & $81.48 \pm 15.23$ & $70.50 \pm 3.84$ & $25.05 \pm 2.37$ & $1323.58 \pm 1679.62$ & 15.57 \\
\hline P17 & $71.13 \pm 23.87$ & $71.76 \pm 2.12$ & $25.93 \pm 2.36$ & $485.58 \pm 119.64$ & 14.14 \\
\hline P18 & $47.95 \pm 40.55$ & $81.53 \pm 10.81$ & $29.08 \pm 5.90$ & $510.35 \pm 272.98$ & 100.00 \\
\hline P19 & $71.10 \pm 24.25$ & $69.95 \pm 4.70$ & $24.98 \pm 1.94$ & $604.93 \pm 284.47$ & 100.00 \\
\hline P20 & $44.56 \pm 27.84$ & $71.38 \pm 4.87$ & $26.15 \pm 2.20$ & $1298.33 \pm 1226.16$ & 100.00 \\
\hline
\end{tabular}


Table IV. Average family richness (AvR), accumulated family richness (AcR), and density (ind $/ \mathrm{m}^{2}$ ) of macroinvertebrates in 20 sites along the Pandeiros River Basin.

\begin{tabular}{crrr}
\hline Sites & AvR & AcR & Density \\
\hline P1 & 11.9 & 29 & 140.9 \\
P2 & 10.5 & 34 & 73.1 \\
P3 & 12.7 & 30 & 245.4 \\
P4 & 15.3 & 38 & 215.9 \\
P5 & 12.7 & 29 & 237.5 \\
P6 & 4.3 & 25 & 13.9 \\
P7 & 13.9 & 33 & 331.8 \\
P8 & 8.8 & 34 & 175.5 \\
P9 & 10.5 & 23 & 172.4 \\
P10 & 8.3 & 32 & 94.3 \\
P11 & 8.8 & 27 & 55.0 \\
P12 & 6.9 & 27 & 143.5 \\
P13 & 9.0 & 31 & 101.2 \\
P14 & 8.6 & 26 & 82.1 \\
P15 & 9.0 & 35 & 146.2 \\
P16 & 8.7 & 27 & 117.7 \\
P17 & 5.8 & 26 & 33.8 \\
P18 & 2.3 & 13 & 26.1 \\
P19 & 4.3 & 20 & 27.1 \\
P20 & 6.3 & 22 & 61.2 \\
\hline
\end{tabular}

did not explain the variation in the community structure, and the shared correlations of the spatial variables with local $(0.2 \%)$ and regional environmental variables (2\%) were extremely low, indicating that space was primarily unimportant in this study. The percentage of explained variation shared among all three matrices was $4.4 \%$. Most of the variation in the macroinvertebrate communities (81\%) remained unexplained (Fig. 3). A single spatial variable was selected $\left(\mathrm{PCNM} 2\right.$, adjusted $\mathrm{R}^{2}=0.081, \mathrm{~F}=$ $2.68, \mathrm{p}<0.001)$. Two local environmental matrix variables were selected: the electrical conductivity (adjusted $\mathrm{R}^{2}=0.117, \mathrm{~F}=1.91$, $\mathrm{p}=0.042$ ) and the pebble fraction (adjusted $\mathrm{R}^{2}=0.072, \mathrm{~F}=2.49$, $\mathrm{p}=0.002$ ). Additionally, two regional environmental matrix variables were selected: non-forest areas (adjusted $\mathrm{R}^{2}=0.073$, $\mathrm{F}=2.49, \mathrm{p}=0.001)$ and average elevation (adjusted $\mathrm{R}^{2}=0.132$, $\mathrm{F}=2.24, \mathrm{p}=0.005$ ) (Fig. 3).

\section{DISCUSSION}

\section{Effects of spatial and environmental patterns on benthic macroinvertebrate communities}

Our results demonstrate that the environmental variables at the local and regional scales (which explained 14.1\% of the total variation) were responsible for structuring the composition (the community composition and relative abundance) of aquatic macroinvertebrate communities. Local-scale

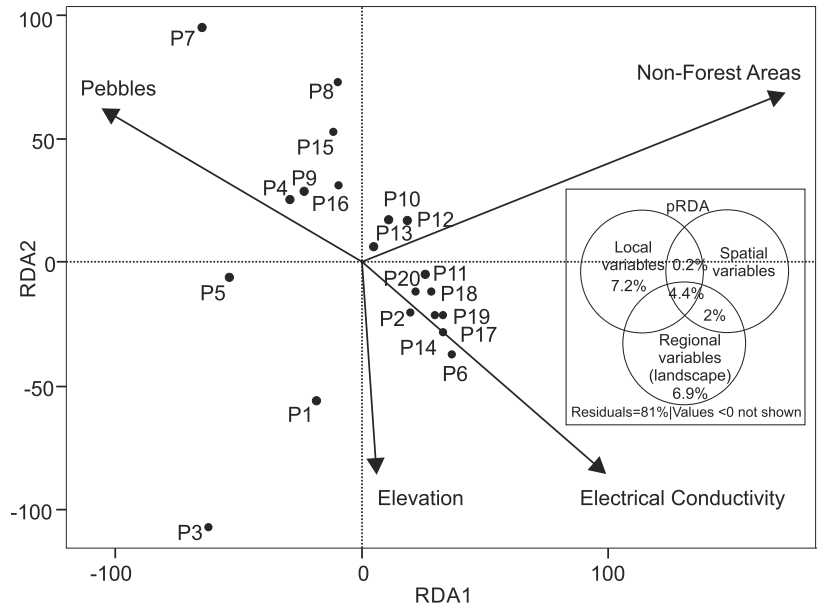

Figure 3. Partial redundancy analysis (pRDA) of the invertebrate communities based on the spatial and local and regional environmental matrices. Percentages of explained variation are shown in the inset Venn diagram.

studies investigating environmental and spatial effects on community variation in Central European (Feld \& Hering 2007) and southern Brazilian streams (Hepp et al. 2012) have obtained similar results. Despite the increased effort to assess the effect of local environmental conditions (7.2\% of explained variation), we found that regional variables (6.9\% of explained variation) can also modify the macroinvertebrate communities. According to Cottenie (2005), most studies that assessed the importance of environmental and spatial variables found that the former, specifically habitat heterogeneity, was the most important. This pattern was also observed for macroinvertebrate communities, which were primarily influenced by niche changes along an environmental gradient (Leibold et al. 2004, Siqueira et al. 2012).

The percentage of explained variation shared by the environmental matrices (local and regional scales) was nearly zero, indicating that the effects of these two groups of variables were independent. The percentages of explained variation shared by spatial and environmental variables (spatial-local $=0.2 \%$ and spatial-regional $=2 \%$ ) were low, indicating that environmental effects are uncorrelated in space. CotTENIE (2005) found that the relative importance of local and regional processes showed the prevalence of three (neutral model, species-sorting, and mass-effect) theoretical metacommunity types for real systems in a unified framework, although we found only an environmental pattern influencing the macroinvertebrate communities (see also Leibold et al. 2004). Although the total percentage of explained variation was low, this pattern is common in ecological studies and is due (at least in part) to important variables that were missing from the analysis or to communities that are not controlled by environmental variables (GENNER et al. 2004, Hepr et al. 2012). 


\section{Effects of environmental variables on benthic macroinvertebrate communities}

The sampling sites with higher family richness and densities of macroinvertebrate communities were associated with the coarse fractions of the substrate, particularly pebbles, in the pRDA ordination. The occurrence of pebbles creates high habitat diversity in the sediment (Dominguez-Granda et al. 2011, Jun et al. 2011), increasing the availability of shelter for aquatic organisms (TuPINAMBas et al. 2007, BÜCKER et al. 2010). Furthermore, high elevations and steep slopes within the landscape provide the streams, which are primarily small, with great strength, increasing their capacity to carry fine sedimentary particles and leaving behind a greater percentage of pebbles (Rosgen 1996, Church 2002). Thus, the flat plains at the bottom of the basin are prime areas for the deposition of fine particles (VANNOTE et al. 1980). This finding corroborates the proposition of VINSON \& HawkINs (2003) that aquatic communities are structured by natural fluvial processes and helps to explain the higher richness and densities of macroinvertebrates in tributary streams (upstream) compared with the Pandeiros River. These natural fluvial processes cause the local habitat characteristics (e.g., water velocity, water depth, river width, and substrate) to vary spatially along the drainage basin (River Continuum Concept; VANNOTE et al. 1980, BÜCKER et al. 2010).

The sampling sites with low taxonomic richness and densities of macroinvertebrate communities were associated with the electrical conductivity and non-forest areas in the pRDA ordination. These variables are associated with effluent discharge and deforestation (MYKRA et al. 2008). Compared with those water bodies in preserved areas, the water bodies in anthropogenic areas have more diffuse sources of organic and inorganic matter, particularly those bodies without vegetative protection, resulting in higher electrical conductivity (GARDINER et al. 2009, Jun et al. 2011). In anthropogenic areas, inadequately treated effluents may flow into adjacent water bodies, increasing the nutrient concentrations of the water and altering the electrical conductivity (MYKRA et al. 2008). In spite of the low percentage of anthropogenic areas within the Pandeiros River Basin, our results suggest negative effects of higher electrical conductivity and non-forest areas on the richnesses and densities of macroinvertebrate communities. Anthropogenic areas (particularly urbanized areas) strongly influence biological communities, and their effects are disproportionate to the size of the area used (PAUl \& MEYer 2001), thus enhancing their real effect on macroinvertebrate communities (JoHnson et al. 2012).

We found that the environmental variables (local and regional) have greater effects on the macroinvertebrate community than do spatial variables. We also identified the most important local (pebble fraction and conductivity) and regional variables (higher altitude and non-forest areas) structuring the macroinvertebrate community. Sampling sites with higher nonforest areas can allow higher inputs of allochthonous soil sediment. Downstream areas (primarily lower altitude) can present higher depositions of fine particles, resulting in low pebble fractions and higher electrical conductivities (contribution by upstream areas). Another aspect is that the pebble fraction can increase habitat diversity and result in a positive effect on the richness and densities of macroinvertebrate communities. Therefore, we conclude that higher percentages of coarse particles (pebbles) in substrates and topographic variation are likely to be responsible for positive effects on family richness and densities of macroinvertebrate communities.

\section{ACKNOWLEDGMENTS}

The authors thank their colleagues at the Benthic Ecology Laboratory (UFMG), the Zoology Laboratory (UNIMONTES), and the Limnology and Aquatic Macrophytes Laboratory (UNIMONTES). The authors also thank the National Council for Scientific and Technological Development (MCT/CNPq/CTHidro, project \#555488/2006-3; MCT/CNPq/CT-Hidro/MMA/MI, project \#555976/2006-8) for providing the financial support to make this project possible. Finally, the authors thank the State Forest Institute of Minas Gerais (IEF) for their logistical support with fieldwork and data collection in the study area. We thank two anonymous reviewers and Adriano S. Melo for their valuable suggestions. English review by American Journal Experts.

\section{LITERATURE CITED}

AlLAN, D.J. 2007. Stream Ecology: Structure and Function of Running Waters. Londres, Chapman and Hall, 436p.

Beisel, J.N.; P. Usseglio-Polatera; S. Thomas \& J.C. Moreteau. 1998. A method to describe substrate heterogeneity at a microhabitat scale. First results on relationships with the macroinvertebrate community structure, p. 39-46. In: G. Bretschio \& J. Helesic (Eds). Advances in River Bottom Ecology. Michigan, Backhuys Publishers.

Blanchet, F.G.; P. LegendRe \& D. BorCARD. 2008. Forward selection of explanatory variables. Ecology 89 (4): 2623-2632. doi: 10.1890/07-0986.1

BorCard, D. \& P. Legendre. 2002. All-scale spatial analysis of ecological data by means of principal coordinates of neighbour matrices. Ecological Modelling 153 (1-2): 51-68. doi: 10.1016/ S0304-3800(01)00501-4

BOYERO, L. \& R.C. BAILEY. 2001. Organization of macroinvertebrate communities at a hierarchy of spatial scales in a tropical stream. Hydrobiologia 464 (1): 219-225. doi: 10.1023/ A:1013922307096

Bücker, A.; M. Sondermann; H.G. Frede \& L. Breuer. 2010. The influence of landuse on macroinvertebrate communities in montane tropical streams - a case study from Ecuador. Fundamental and Applied Limnology/Archiv für Hydrobiologie 177 (4): 267-282. doi: 10.1127/1863-9135/2010/0177-0267

Callisto, M. \& F. Esteves. 1996. Composicão granulométrica do sedimento de um lago amazônico impactado por rejeito de 
bauxita e um lago natural. Acta Limnologica Brasiliensia 8 (1): 115-126.

Carmouze, J.P. 1994. O Metabolismo dos Ecossistemas Aquáticos. Fundamentos teóricos, métodos de estudo e análises químicas. São Paulo Edgard Blucher, FAPESP, 254p.

Church, M. 2002. Geomorphic thresholds in riverine landscapes. Freshwater Biology 47 (4): 541-557. doi: 10.1046/j.1365-2427.2002.00919.x

Costa, S.S. \& A.S. Melo. 2007. Beta diversity in stream macroinvertebrate assemblages: among-site and amongmicrohabitat components. Hydrobiologia 598 (1): 131-138. doi: 10.1007/s10750-007-9145-7

CotTenie, K. 2005. Integrating environmental and spatial processes in ecological community dynamics. Ecology Letter 8 (11): 1175-1182. doi: 10.1111/j.1461-0248.2005.00820.x

Cummins, K.; R. Merritt \& P. Andrade. 2005. The use of invertebrate functional groups to characterize ecosystem attributes in selected streams and rivers in south Brazil. Studies on Neotropical Fauna and Environment 40 (1): 69-89. doi: 10.1080/01650520400025720

Dennison, P.E.; P.L. Nagler; K.R. Hultine; E.P. Glenn \& J.R. EHLERINGER. 2009. Remote monitoring of tamarisk defoliation and evapotranspiration following saltcedar leaf beetle attack. Remote Sensing of Environment 113 (7): 1462-1472. doi: 10.1016/j.rse.2008.05.022

Dominguez-Granda, L.; K. Lock \& P.L.M. Goethals. 2011. Using multi-target clustering trees as a tool to predict biological water quality indices based on benthic macroinvertebrates and environmental parameters in the Chaguana watershed (Ecuador). Ecological Informatics 6 (5): 303-308. doi: 10.1016/j.ecoinf.2011.05.004

Dray, S.; P. Legendre \& P.R. Peres-Neto. 2006. Spatial modelling: a comprehensive framework for principal coordinate analysis of neighbour matrices (PCNM). Ecological Modelling 196 (3-4): 483-493. doi: 10.1016/j.ecolmodel.2006.02.015

Feld, C.K. \& D. Hering. 2007. Community structure or function: effects of environmental stress on benthic macroinvertebrates at different spatial scales. Freshwater Biology 52 (7): 13801399. doi: 10.1111/j.1365-2427.2007.01749.x

Ferreira, W.R.; L.T. Paiva \& M. Callisto. 2011. Development of a benthic multimetric index for biomonitoring of a neotropical watershed. Brazilian Journal of Biology 71 (1): 15-25.

Gardiner, E.P.; A.B. SutherLand; R.J. Bixby; M.C. ScotT; J.L. Meyer; G.S. Helfman; E.F. Benfield; C.M. Pringle; P.V. Bolstad \& D.N. WEAR. 2009. Linking stream and landscape trajectories in the southern Appalachians. Environmental monitoring and assessment 156 (1-4): 17-36. doi: 10.1007/s10661-008-0460-X

Genner, M.J.; M.I. Taylor; D.F.R. Cleary; S.J. HaWkins; M.E. Knight \& G.F. TURNER. 2004. Beta diversity of rock-restricted cichlid fishes in Lake Malawi: importance of environmental and spatial variables. Ecography 27 (5): 601-610. doi: 10.1111/ j.0906-7590.2004.03824.x
Harper, D.; J. Meкotova; S. Hulme; J. White \& J. Hall. 1997. Habitat Heterogeneity and Aquatic Invertebrate Diversity in Floodplain Forests. Global Ecology and Biogeography Letters 6 (3-4): 275-285.

Hepr, L.U.; V.L. Landeiro \& A.S. Melo. 2012. Experimental Assessment of the Effects of Environmental Variables and Longitudinal Position on Alpha and Beta Diversities of Aquatic Insects in a Neotropical Stream. International Review of Hydrobiology 97 (2): 157-167. doi: 10.1002/iroh.201111405

HolYoAK, M; M.A. Leibold \& R.D. Holt. 2005. Metacommunities: spatial dynamics and ecological communities. Chicago, University of Chicago Press, 513p.

Hubbell, S.P. 2001. The Unified Neutral Theory of Biodiversity and Biogeography. Princeton, Princeton University Press, $448 \mathrm{p}$.

Johnson, R.C.; D.P. Smith \& C.E. Mcmichael. 2012. Scale Dependence in Relating Land Use/Cover to Stream Macroinvertebrate Communities in the Central Appalachian Mountains, USA. Science \& Remote Sensing 49 (1): 53-70. doi: 10.2747/1548-1603.49.1.53

Jun, Y.C.; N.Y. Kim; S.J. Kwon; S.C. Han; I.C. Hwang; J.H. ParK; D.H. Won; M.S. Byun; H.Y. Kong; J.E. Lee \& S.J. Hwang. 2011. Effects of land use on benthic macroinvertebrate communities: Comparison of two mountain streams in Korea. Annales de Limnologie - International Journal of Limnology 47 (1): S35-S49. doi: 10.1051/LIMN/2011018

Leibold, M.A.; M. Holyoak; N. Mouquet; P. Amarasekare; J.M. Chase; M.F. Hoopes; R.D. Holt; J.B. Shurin; R. LaW; D. Tilman; M. Loreau \& A. Gonzalez. 2004. The metacommunity concept: a framework for multi-scale community ecology. Ecology Letters 7 (7): 601-613.

MeLo, A.S. 2009. Explaining dissimilarities in macroinvertebrate assemblages among stream sites using environmental variables. Zoologia 26 (1): 79-84. doi: 10.1590/S198446702009000100013

Merrit, R.W. \& K.W. Cummins. 1996. An introduction to the aquatic insects of North America. Dubuque, Kendall/Hunt Publishing Company, 862p.

Moreno, P.; J.S. Franca; W.R. Ferreira; A.D. Paz; I.M. Monteiro \& M. CALLISTO. 2009. Use of the BEAST model for biomonitoring water quality in a neotropical basin. Hydrobiologia 630 (1): 231-242. doi: 10.1007/s10750-009-9796-7

Mykra, H.; J. Arovitta; H. Hamalainen; J. Kotanen; K.M. Vuori \& T. Muотка. 2008. Assessing stream condition using macro invertebrates and macrophytes: concordance of community responses to human impact. Fundamental and Applied Limnology 172 (3): 191-203. doi: 10.1127/1863-9135/2008/ 0172-0191

Nessimian, J.L.; E.M. Venticingue; J. Zuanon; P. Marco; M. Gordo; L. Fidelis; J. D'arc Batista \& L. Juen. 2008. Land use, habitat integrity, and aquatic insect assemblages in Central Amazonian streams. Hydrobiologia 614 (1): 117-131. doi: 10.1007/s10750-008-9441-x 
Oksanen, J.; F.G. Blanchet; R. Kindt; P. Legendre; P.R. Minchin; R.B. O’Hara; G.L. Simpson; P. Solymos; M. Henry; H. Stevens \& H. Wagner. 2013. Community Ecology Package: Ordination, Diversity and Dissimilarities. version 2.0-8. Available online at: http://cran.r-project.org/web/packages/vegan/ index.html [Accessed: 16/V/2013]

Onoda, Y.; A. Maruyama; Y. Kohmatsu \& M. Yuma. 2009. The relative importance of substrate conditions as microhabitat determinants of a riverine benthic goby, Rhinogobius sp. OR (orange form) in runs. Limnology 10 (1): 57-61. doi: 10.1007/s10201-008-0259-Z

Park, S.R.; H.J. Lee; S.W. Lee; S.J. Hwang; M.S. Byeon; G.J. Joo; K.S. Jeong; D.S. Kong \& M.C. KIm. 2011. Relationships between land use and multi-dimensional characteristics of streams and rivers at two different scales. Annales de Limnologie - International Journal of Limnology 47 (1): S107S116.

Paul, M.J. \& J.L. Meyer. 2001. Streams in the Urban Landscape. Annual Review of Ecology and Systematics 32 (1): 333365. doi: 10.1051/limn/2011023

Peres-Neto, P.R.; P. Legendre; S. Dray \& D. Borcard. 2006. Variation partitioning of species data matrices: estimation and comparison of fractions. Ecology 87 (10): 2614-2625. doi: 10.1890/0012-9658(2006)87[2614:VPOSDM]2.0.CO;2

Perez, G.P. 1988. Guía para el studio de los macroinvertebrados acuáticos del departamento de Antioquia. Bogota, Editorial Presencia Ltda, 217p.
Rosgen, D.L. 1996. Applied River Morphology. Pagosa, Springs, 390p.

Rouse, J.W.; R.H. HaAs; J.A. Schell \& D.W. Deering. 1973. Deering, Monitoring vegetation systems in the Great Plains with ERTS, p. 309-317. In: Proceedings of the Proceedings of the Third ERTS Symposium. Washington, D.C., NASA.

Siqueira, T.; L.M. Bini; F.O. Roque \& K. Cottenie. 2012. A metacommunity framework for enhancing the effectiveness of biological monitoring strategies. PLoS One 7 (8): e43626. doi: 10.1371/journal.pone.0043626

Suguio, K. 1973. Introdução à sedimentologia. São Paulo, Edgard Blucher, 317p.

R Development Core Team 2013. R: A language and environment for statistical computing. Vienna, $\mathrm{R}$ Foundation for Statistical Computing, $\mathrm{R}$ version 3.0.1, ISBN 3-900051-07-0. Available online at: http://www.Rproject.org. [Accessed: 16/V/2013]

Tupinambas, T.H.; M. Callisto \& G.B. Santos. 2007. Benthic macroinvertebrate assemblages structure in two headwater streams, south-eastern Brazil. Revista Brasileira de Zoologia 24 (4): 887-897. doi: 10.1590/S0101-81752007000400005

Vannote, R.L.; G.W. Minshall; K.W. Cummins; J.R. Sedell \& C.E. Cushing. 1980. River Continuum Concept. Canadian Journal of Fisheries and Aquatic Sciences 37 (3): 130-137.

VInson, M.R. \& C.P. HAwKIns. 2003. Broad-scale geographical patterns in local stream insect genera richness. Ecography 26 (1): 751-767. doi: 10.1111/j.0906-7590.2003.03397.x

Submitted: 21.VIII.2013; Accepted: 29.VII.2014.

Editorial responsibility: Adriano S. Melo

ZOOLOGIA 31 (5): 426-434, October, 2014 
Appendix S1. Base watershed Otto-coded and geographical location of the river (UTM). Bold-faced code indicates the level of otto-bacia (Otto5) used in segregation of the regions.

\begin{tabular}{|c|c|c|c|c|c|c|c|c|c|}
\hline Sites & Otto1 & Otto2 & Otto3 & Otto4 & Otto5 & Otto6 & Lat_Sad69 & Long-Sad69 & Geographical location - UTM \\
\hline P1 & 7 & 74 & 747 & 7472 & 74729 & 747291 & -15.185 & -45.124 & 23 L 4870788321388 \\
\hline $\mathrm{P} 2$ & 7 & 74 & 747 & 7472 & 74728 & 747281 & -15.222 & -45.139 & 23 L 4850848317123 \\
\hline P3 & 7 & 74 & 747 & 7472 & 74727 & 747279 & -15.255 & -45.087 & 23 L 4907668313432 \\
\hline P4 & 7 & 74 & 747 & 7472 & 74727 & 747274 & -15.257 & -44.963 & 23 L 5053768312902 \\
\hline P5 & 7 & 74 & 747 & 7472 & 74727 & 747276 & -15.262 & -45.014 & 23 L 4985268312719 \\
\hline P6 & 7 & 74 & 747 & 7472 & 74727 & 747275 & -15.282 & -45.013 & 23 L 4986798310507 \\
\hline P7 & 7 & 74 & 747 & 7472 & 74726 & 747263 & -15.290 & -44.822 & 23 L 5191328309678 \\
\hline P8 & 7 & 74 & 747 & 7472 & 74726 & 747262 & -15.384 & -44.945 & 23 L 5059638299244 \\
\hline P9 & 7 & 74 & 747 & 7472 & 74725 & 747252 & -15.457 & -44.859 & 23 L 5152108291122 \\
\hline $\mathrm{P} 10$ & 7 & 74 & 747 & 7472 & 74725 & 747251 & -15.441 & -44.822 & 23 L 5191658292960 \\
\hline P11 & 7 & 74 & 747 & 7472 & 74723 & 747231 & -15.456 & -44.789 & 23 L 5226158291137 \\
\hline $\mathrm{P} 12$ & 7 & 74 & 747 & 7472 & 74723 & 747232 & -15.455 & -44.790 & 23 L 5226798291483 \\
\hline P13 & 7 & 74 & 747 & 7472 & 74724 & 747241 & -15.423 & -44.789 & 23 L 5227348294876 \\
\hline $\mathrm{P} 14$ & 7 & 74 & 747 & 7472 & 74722 & 747221 & -15.477 & -44.744 & 23 L 5274808288900 \\
\hline P15 & 7 & 74 & 747 & 7472 & 74721 & 747212 & -15.514 & -44.754 & 23 L 5264438284887 \\
\hline P16 & 7 & 74 & 747 & 7472 & 74721 & 747212 & -15.519 & -44.754 & 23 L 5265238284205 \\
\hline P17 & 7 & 74 & 747 & 7472 & 74721 & 747211 & -15.606 & -44.711 & 23 L 5310238274679 \\
\hline P18 & 7 & 74 & 747 & 7472 & 74721 & 747211 & -15.667 & -44.635 & 23 L 5392128267918 \\
\hline P19 & 7 & 74 & 747 & 7472 & 74721 & 747211 & -15.667 & -44.639 & 23 L 5387548267922 \\
\hline P20 & 7 & 74 & 747 & 7472 & 74721 & 747211 & -15.683 & -44.610 & 23 L 5418418266150 \\
\hline
\end{tabular}




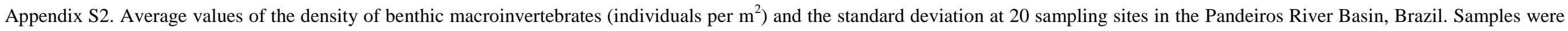
obtained during February, May, September and November of 2008.

\begin{tabular}{|c|c|c|c|c|c|c|c|c|c|c|c|c|c|c|c|c|c|c|c|c|c|c|c|c|c|c|c|c|c|c|c|}
\hline \multirow{2}{*}{$\begin{array}{c}\text { Taxa } \\
\text { Nematoda }\end{array}$} & \multicolumn{3}{|c|}{ P1 } & \multicolumn{3}{|c|}{$\mathrm{P} 2$} & \multicolumn{3}{|c|}{ P3 } & \multicolumn{3}{|c|}{$\mathrm{P} 4$} & \multicolumn{3}{|c|}{ P5 } & \multicolumn{3}{|c|}{ P6 } & \multicolumn{3}{|c|}{ P7 } & & \multicolumn{3}{|c|}{ P8 } & \multicolumn{3}{|c|}{ P9 } & \multicolumn{3}{|c|}{ P10 } \\
\hline & & & & & & & & & & & & & & & & & & & & & & & & & & & & & & & \\
\hline $\begin{array}{l}\text { Nematomorpha } \\
\text { Annelida. }\end{array}$ & 0 & \pm & 0 & 0 & \pm & 0 & 0 & \pm & 0 & 9 & \pm & 32 & 0 & \pm & 0 & 0 & \pm & 0 & 0 & \pm & 0 & \pm & 37 & \pm & 128 & 0 & \pm & 0 & 0 & \pm & 0 \\
\hline Hyrundinae & 0 & \pm & 0 & 0 & \pm & 0 & 19 & \pm & 43 & 0 & \pm & 0 & 0 & \pm & 0 & 0 & \pm & 0 & 0 & \pm & 0 & \pm & 102 & \pm & 266 & 0 & \pm & 0 & 9 & \pm & 32 \\
\hline Oligochaeta & 74 & \pm & 128 & 176 & \pm & 575 & 111 & \pm & 288 & 176 & \pm & 316 & 194 & \pm & 345 & 28 & \pm & 96 & 231 & \pm & 330 & \pm & 426 & \pm & 734 & 296 & \pm & 482 & 83 & \pm & 126 \\
\hline Mollusca & & & & & & & & & & & & & & & & & & & & & & & & & & & & & & & \\
\hline $\begin{array}{l}\text { Bivalvia } \\
\text { Gastropoda }\end{array}$ & 0 & \pm & 0 & 56 & \pm & 89 & 0 & \pm & 0 & 148 & \pm & 261 & 324 & \pm & 286 & 19 & \pm & 64 & 0 & \pm & 0 & \pm & 19 & \pm & 64 & 0 & \pm & 0 & 120 & \pm & 383 \\
\hline Ampullariidae & 0 & \pm & 0 & 0 & \pm & 0 & 0 & \pm & 0 & 0 & \pm & 0 & 0 & \pm & 0 & 0 & \pm & 0 & 0 & \pm & 0 & \pm & 0 & \pm & 0 & 0 & \pm & 0 & 0 & \pm & 0 \\
\hline Planorbidae & 0 & \pm & 0 & 0 & \pm & 0 & 19 & \pm & 43 & 9 & \pm & 32 & 0 & \pm & 0 & 0 & \pm & 0 & 0 & \pm & 0 & \pm & 9 & \pm & 32 & 0 & \pm & 0 & 0 & \pm & 0 \\
\hline Lymnaeidae & 0 & \pm & 0 & 120 & \pm & 326 & 0 & \pm & 0 & 37 & \pm & 99 & 0 & \pm & 0 & 0 & \pm & 0 & 0 & \pm & 0 & \pm & 0 & \pm & 0 & 0 & \pm & 0 & 0 & \pm & 0 \\
\hline Thiaridae & 0 & \pm & 0 & 37 & \pm & 128 & 9 & \pm & 32 & 194 & \pm & 339 & 0 & \pm & 0 & 0 & \pm & 0 & 0 & \pm & 0 & \pm & 0 & \pm & 0 & 0 & \pm & 0 & 0 & \pm & 0 \\
\hline Pomaceae & 0 & \pm & 0 & 0 & \pm & 0 & 0 & \pm & 0 & 0 & \pm & 0 & 0 & \pm & 0 & 0 & \pm & 0 & 0 & \pm & 0 & \pm & 0 & \pm & 0 & 0 & \pm & 0 & 0 & \pm & 0 \\
\hline $\begin{array}{l}\text { Arthropoda } \\
\text { Chelicerata } \\
\text { Arachnida }\end{array}$ & & & & & & & & & & & & & & & & & & & & & & & & & & & & & & & \\
\hline $\begin{array}{l}\text { Aracmimua } \\
\text { Hydracarina } \\
\text { Crustacea } \\
\text { Malacostracoda } \\
\text { Decapoda }\end{array}$ & 37 & \pm & 99 & 120 & \pm & 350 & 9 & \pm & 32 & 148 & \pm & 513 & 9 & \pm & 32 & 28 & \pm & 69 & 37 & \pm & 128 & \pm & 0 & \pm & 0 & 28 & \pm & 69 & 19 & \pm & 64 \\
\hline $\begin{array}{l}\text { Paleomonidae } \\
\text { Amphipoda }\end{array}$ & 0 & \pm & 0 & 19 & \pm & 43 & 361 & \pm & 1183 & 19 & \pm & 64 & 0 & \pm & 0 & 0 & \pm & 0 & 0 & \pm & 0 & \pm & 0 & \pm & 0 & 0 & \pm & 0 & 0 & \pm & 0 \\
\hline $\begin{array}{l}\text { Hyalidae } \\
\text { Branchiopoda }\end{array}$ & 0 & \pm & 0 & 0 & \pm & 0 & 398 & \pm & 414 & 0 & \pm & 0 & 0 & \pm & 0 & 0 & \pm & 0 & 0 & \pm & 0 & \pm & 0 & \pm & 0 & 0 & \pm & 0 & 0 & \pm & 0 \\
\hline Cladocera & 0 & \pm & 0 & 0 & \pm & 0 & 0 & \pm & 0 & 0 & \pm & 0 & 0 & \pm & 0 & 0 & \pm & 0 & 278 & \pm & 895 & \pm & 0 & \pm & 0 & 0 & \pm & 0 & 0 & \pm & 0 \\
\hline $\begin{array}{l}\text { Ostracoda } \\
\text { Maxillopoda }\end{array}$ & 37 & \pm & 128 & 0 & \pm & 0 & 0 & \pm & 0 & 28 & \pm & 96 & 0 & \pm & 0 & 9 & \pm & 32 & 0 & \pm & 0 & \pm & 19 & \pm & 64 & 0 & \pm & 0 & 0 & \pm & 0 \\
\hline $\begin{array}{l}\text { Copepoda } \\
\text { Atelocerata } \\
\text { Hexapoda }\end{array}$ & 0 & \pm & 0 & 0 & \pm & 0 & 0 & \pm & 0 & 0 & \pm & 0 & 0 & \pm & 0 & 9 & \pm & 32 & 111 & \pm & 385 & \pm & 0 & \pm & 0 & 0 & \pm & 0 & 0 & \pm & 0 \\
\hline $\begin{array}{l}\text { Collembola } \\
\text { Insecta }\end{array}$ & 0 & \pm & 0 & 0 & \pm & 0 & 9 & \pm & 32 & 0 & \pm & 0 & 0 & \pm & 0 & 0 & \pm & 0 & 0 & \pm & 0 & \pm & 0 & \pm & 0 & 0 & \pm & 0 & 0 & \pm & 0 \\
\hline Ephemeroptera & & & & & & & & & & & & & & & & & & & & & & & & & & & & & & & \\
\hline Leptophlebiidae & 306 & \pm & 432 & 111 & \pm & 251 & 2315 & \pm & 3120 & 1102 & \pm & 697 & 491 & \pm & 640 & 9 & \pm & 32 & 1343 & \pm & 2056 & \pm & 83 & \pm & 256 & 259 & \pm & 467 & 231 & \pm & 606 \\
\hline Leptohyphiidae & 343 & \pm & 305 & 648 & \pm & 995 & 676 & \pm & 598 & 2102 & \pm & 2768 & 1713 & \pm & 2072 & 28 & \pm & 69 & 3620 & \pm & 4313 & \pm & 3370 & \pm & 4266 & 1370 & \pm & 1772 & 1426 & \pm & 3029 \\
\hline Baetidae & 935 & \pm & 1033 & 306 & \pm & 421 & 389 & \pm & 687 & 435 & \pm & 500 & 1241 & \pm & 1062 & 148 & \pm & 191 & 4056 & \pm & 5626 & \pm & 1222 & \pm & 1867 & 1537 & \pm & 1927 & 176 & \pm & 274 \\
\hline Caenidae & 0 & \pm & 0 & 19 & \pm & 43 & 0 & \pm & 0 & 0 & \pm & 0 & 0 & \pm & 0 & 9 & \pm & 32 & 0 & \pm & 0 & \pm & 111 & \pm & 385 & 185 & \pm & 435 & 19 & \pm & 64 \\
\hline Oligoneuriidae & 56 & \pm & 101 & 9 & \pm & 32 & 0 & \pm & 0 & 0 & \pm & 0 & 46 & \pm & 129 & 9 & \pm & 32 & 0 & \pm & 0 & \pm & 0 & \pm & 0 & 0 & \pm & 0 & 0 & \pm & 0 \\
\hline Polymitarcyidae & 0 & \pm & 0 & 0 & \pm & 0 & 0 & \pm & 0 & 0 & \pm & 0 & 0 & \pm & 0 & 0 & \pm & 0 & 0 & \pm & 0 & \pm & 0 & \pm & 0 & 9 & \pm & 32 & 0 & \pm & 0 \\
\hline Euthyplociidae & 0 & \pm & 0 & 9 & \pm & 32 & 0 & \pm & 0 & 0 & \pm & 0 & 0 & \pm & 0 & 0 & \pm & 0 & 9 & \pm & 32 & \pm & 9 & \pm & 32 & 213 & \pm & 186 & 37 & \pm & 99 \\
\hline $\begin{array}{l}\text { Odonata } \\
\text { Zygoptera }\end{array}$ & & & & & & & & & & & & & & & & & & & & & & & & & & & & & & & \\
\hline Coenagrionidae & 19 & \pm & 43 & 46 & \pm & 74 & 139 & \pm & 143 & 194 & \pm & 300 & 37 & \pm & 72 & 0 & \pm & 0 & 46 & \pm & 88 & \pm & 435 & \pm & 541 & 46 & \pm & 88 & 28 & \pm & 96 \\
\hline Calopterigidae & 0 & \pm & 0 & 0 & \pm & 0 & 0 & \pm & 0 & 9 & \pm & 32 & 9 & \pm & 32 & 37 & \pm & 128 & 0 & \pm & 0 & \pm & 0 & \pm & 0 & 0 & \pm & 0 & 9 & \pm & 32 \\
\hline Anisoptera & & & & & & & & & & & & & & & & & & & & & & & & & & & & & & & \\
\hline Libellulidae & 389 & \pm & 611 & 9 & \pm & 32 & 65 & \pm & 88 & 380 & \pm & 507 & 167 & \pm & 353 & 19 & \pm & 43 & 361 & \pm & 207 & \pm & 722 & \pm & 765 & 685 & \pm & 726 & 102 & \pm & 253 \\
\hline Gomphidae & 37 & \pm & 99 & 46 & \pm & 100 & 83 & \pm & 126 & 389 & \pm & 350 & 259 & \pm & 269 & 37 & \pm & 72 & 93 & \pm & 156 & \pm & 28 & \pm & 69 & 352 & \pm & 288 & 130 & \pm & 288 \\
\hline Aeshnidae & 0 & \pm & 0 & 0 & \pm & 0 & 0 & \pm & 0 & 0 & \pm & 0 & 0 & \pm & 0 & 0 & \pm & 0 & 0 & \pm & 0 & \pm & 0 & \pm & 0 & 0 & \pm & 0 & 0 & \pm & 0 \\
\hline Plecoptera & & & & & & & & & & & & & & & & & & & & & & & & & & & & & & & \\
\hline $\begin{array}{l}\text { Perlidae } \\
\text { Hemiptera }\end{array}$ & 213 & \pm & 353 & 28 & \pm & 50 & 0 & \pm & 0 & 287 & \pm & 386 & 9 & \pm & 32 & 19 & \pm & 64 & 111 & \pm & 222 & \pm & 0 & \pm & 0 & 0 & \pm & 0 & 19 & \pm & 64 \\
\hline Pleidae & 0 & \pm & 0 & 0 & \pm & 0 & 19 & \pm & 43 & 9 & \pm & 32 & 444 & \pm & 506 & 0 & \pm & 0 & 167 & \pm & 443 & \pm & 0 & \pm & 0 & 0 & \pm & 0 & 0 & \pm & 0 \\
\hline Naucoridae & 130 & \pm & 182 & 130 & \pm & 141 & 324 & \pm & 270 & 231 & \pm & 386 & 426 & \pm & 516 & 0 & \pm & 0 & 37 & \pm & 72 & \pm & 65 & \pm & 120 & 0 & \pm & 0 & 37 & \pm & 128 \\
\hline Notonectidae & 0 & \pm & 0 & 0 & \pm & 0 & 0 & \pm & 0 & 0 & \pm & 0 & 0 & \pm & 0 & 9 & \pm & 32 & 0 & \pm & 0 & \pm & 37 & \pm & 128 & 0 & \pm & 0 & 0 & \pm & 0 \\
\hline Gerridae & 0 & \pm & 0 & 0 & \pm & 0 & 0 & \pm & 0 & 0 & \pm & 0 & 9 & \pm & 32 & 28 & \pm & 69 & 0 & \pm & 0 & \pm & 19 & \pm & 64 & 0 & \pm & 0 & 139 & \pm & 332 \\
\hline
\end{tabular}




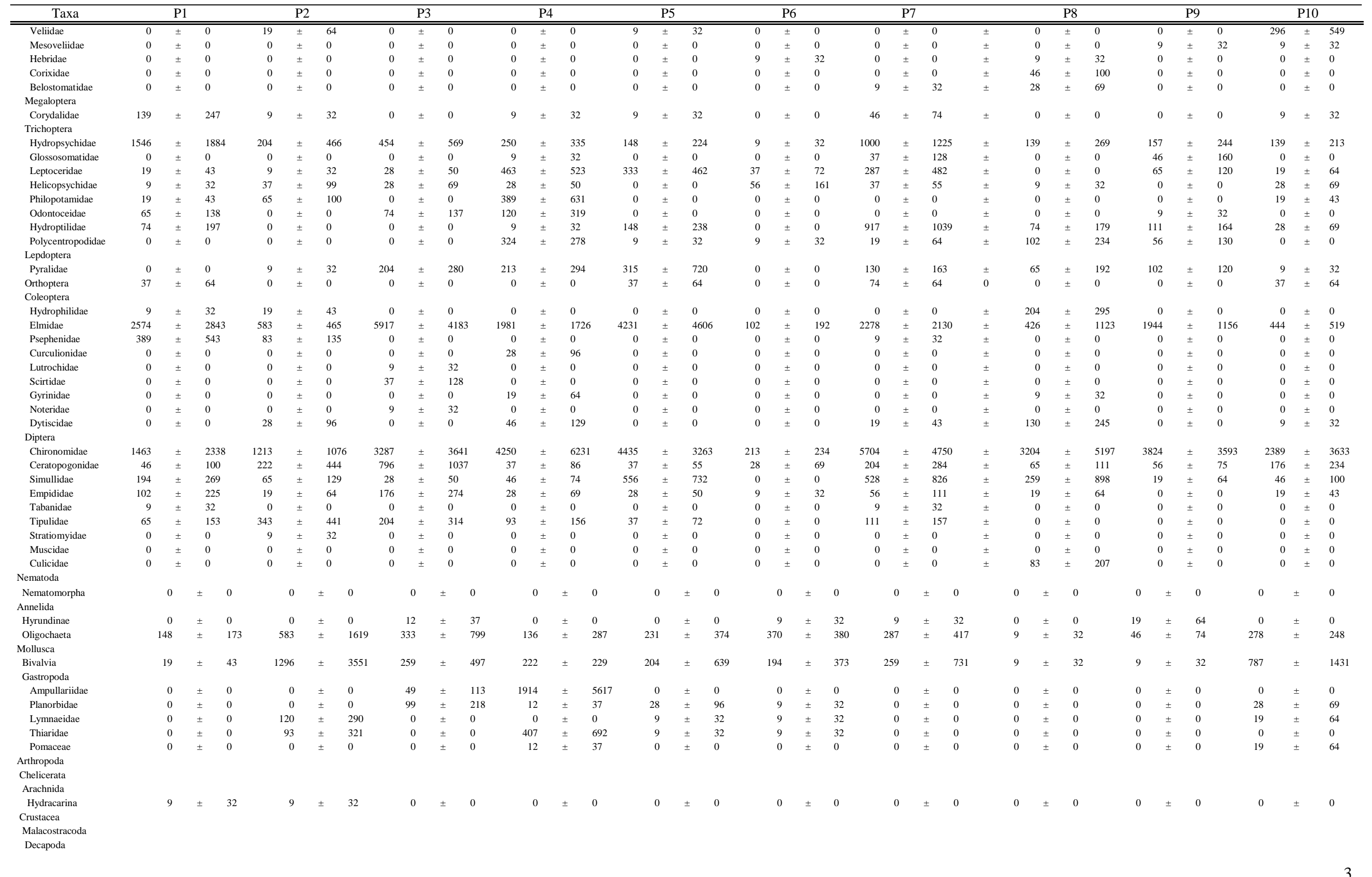




\begin{tabular}{|c|c|c|c|c|c|c|c|c|c|c|c|c|c|c|c|c|c|c|c|c|c|c|c|c|c|c|c|c|c|c|}
\hline $\begin{array}{c}\text { Taxa } \\
\text { Paleomonidae }\end{array}$ & \multicolumn{3}{|c|}{$\mathrm{P} 1$} & \multicolumn{3}{|c|}{$\mathrm{P} 2$} & \multicolumn{3}{|c|}{ P3 } & \multicolumn{3}{|c|}{ P4 } & \multicolumn{3}{|c|}{ P5 } & \multicolumn{3}{|c|}{ P6 } & \multicolumn{3}{|c|}{ P7 } & & & P8 & & & P9 & & & \\
\hline $\begin{array}{l}\text { Hyalidae } \\
\text { Branchionoda }\end{array}$ & 19 & \pm & 64 & 0 & \pm & 0 & 12 & \pm & 37 & 0 & \pm & 0 & 0 & \pm & 0 & 0 & \pm & 0 & 19 & \pm & 43 & 0 & \pm & 0 & 0 & \pm & 0 & 0 & \pm & 0 \\
\hline Cladocera & 0 & \pm & 0 & 0 & \pm & 0 & 0 & \pm & 0 & 0 & \pm & 0 & 0 & \pm & 0 & 0 & \pm & 0 & 0 & \pm & 0 & 0 & \pm & 0 & 0 & \pm & 0 & 0 & \pm & 0 \\
\hline $\begin{array}{l}\text { Ostracoda } \\
\text { Maxillopoda }\end{array}$ & 0 & \pm & 0 & 0 & \pm & 0 & 0 & \pm & 0 & 12 & \pm & 37 & 0 & \pm & 0 & 56 & \pm & 138 & 9 & \pm & 32 & 0 & \pm & 0 & 19 & \pm & 64 & 9 & \pm & 32 \\
\hline $\begin{array}{l}\text { Copepoda } \\
\text { Atelocerata } \\
\text { Hexapoda }\end{array}$ & 0 & \pm & 0 & 0 & \pm & 0 & 0 & \pm & 0 & 0 & \pm & 0 & 0 & \pm & 0 & 0 & \pm & 0 & 0 & \pm & 0 & 0 & \pm & 0 & 0 & \pm & 0 & 0 & \pm & 0 \\
\hline $\begin{array}{l}\text { Collembola } \\
\text { Insecta }\end{array}$ & 0 & \pm & 0 & 0 & \pm & 0 & 0 & \pm & 0 & 0 & \pm & 0 & 9 & \pm & 32 & 0 & \pm & 0 & 0 & \pm & 0 & 9 & \pm & 32 & 0 & \pm & 0 & 0 & \pm & 0 \\
\hline Ephemeroptera & & & & & & & & & & & & & & & & & & & & & & & & & & & & & & \\
\hline $\begin{array}{l}\text { Leptophlebiidae } \\
\text { Leptohyphiidae }\end{array}$ & $\begin{array}{r}28 \\
907\end{array}$ & $\begin{array}{l} \pm \\
\pm\end{array}$ & $\begin{array}{l}69 \\
566\end{array}$ & $\begin{array}{l}102 \\
630\end{array}$ & $\begin{array}{l} \pm \\
\pm\end{array}$ & 286 & 198 & $\begin{array}{l} \pm \\
\pm\end{array}$ & $\begin{array}{l}271 \\
798\end{array}$ & 99 & \pm & $\begin{array}{l}152 \\
516\end{array}$ & 46 & \pm & $\begin{array}{l}74 \\
2679\end{array}$ & $\begin{array}{r}0 \\
37\end{array}$ & $\begin{array}{l} \pm \\
\pm\end{array}$ & $\begin{array}{l}0 \\
99\end{array}$ & $\begin{array}{r}0 \\
28\end{array}$ & $\begin{array}{l} \pm \\
\pm\end{array}$ & $\begin{array}{l}0 \\
50\end{array}$ & $\begin{array}{r}0 \\
37\end{array}$ & \pm & 0 & $\begin{array}{r}9 \\
5\end{array}$ & \pm & $\begin{array}{l}32 \\
161\end{array}$ & 19 & \pm & $\begin{array}{l}64 \\
1446\end{array}$ \\
\hline $\begin{array}{l}\text { Leptohyphiidae } \\
\text { Baetidae }\end{array}$ & 250 & \pm & $\begin{array}{l}566 \\
285\end{array}$ & 778 & \pm & $\begin{array}{l}804 \\
1670\end{array}$ & $\begin{array}{l}543 \\
247\end{array}$ & \pm & $\begin{array}{l}798 \\
368\end{array}$ & $\begin{array}{r}303 \\
99\end{array}$ & \pm & $\begin{array}{l}516 \\
141\end{array}$ & $\begin{array}{r}1852 \\
963\end{array}$ & \pm & $\begin{array}{l}2679 \\
1391\end{array}$ & 306 & \pm & 397 & $\begin{array}{r}28 \\
167\end{array}$ & \pm & 305 & 19 & $\begin{array}{l} \pm \\
\pm\end{array}$ & $\begin{array}{l}99 \\
43\end{array}$ & $\begin{array}{r}56 \\
120\end{array}$ & $\begin{array}{l} \pm \\
\pm\end{array}$ & $\begin{array}{l}161 \\
316\end{array}$ & $\begin{array}{l}602 \\
231\end{array}$ & $\begin{array}{l} \pm \\
\pm\end{array}$ & $\begin{array}{l}1446 \\
425\end{array}$ \\
\hline Caenidae & 0 & \pm & 0 & 0 & \pm & 0 & 0 & \pm & 0 & 235 & \pm & 466 & 111 & \pm & 385 & 0 & \pm & 0 & 9 & \pm & 32 & 0 & \pm & 0 & 9 & \pm & 32 & 0 & \pm & 0 \\
\hline Oligoneuriidae & 19 & \pm & 43 & 0 & \pm & 0 & 0 & \pm & 0 & 0 & \pm & 0 & 0 & \pm & 0 & 0 & \pm & 0 & 0 & \pm & 0 & 0 & \pm & 0 & 0 & \pm & 0 & 0 & \pm & 0 \\
\hline Polymitarcyidae & 0 & \pm & 0 & 0 & \pm & 0 & 0 & \pm & 0 & 0 & \pm & 0 & 0 & \pm & 0 & 0 & \pm & 0 & 28 & \pm & 69 & 0 & \pm & 0 & 0 & \pm & 0 & 0 & \pm & 0 \\
\hline Euthyplociidae & 0 & \pm & 0 & 0 & \pm & 0 & 0 & \pm & 0 & 0 & \pm & 0 & 0 & \pm & 0 & 0 & \pm & 0 & 28 & \pm & 96 & 0 & \pm & 0 & 0 & \pm & 0 & 0 & \pm & 0 \\
\hline $\begin{array}{l}\text { Odonata } \\
\text { Zygoptera }\end{array}$ & & & & & & & & & & & & & & & & & & & & & & & & & & & & & & \\
\hline Coenagrionidae & 9 & \pm & 32 & 56 & \pm & 89 & 25 & \pm & 49 & 173 & \pm & 168 & 9 & \pm & 32 & 380 & \pm & 798 & 102 & \pm & 153 & 0 & \pm & 0 & 65 & \pm & 225 & 0 & \pm & 0 \\
\hline Calopterigidae & 0 & \pm & 0 & 0 & \pm & 0 & 25 & \pm & 74 & 0 & \pm & 0 & 9 & \pm & 32 & 0 & \pm & 0 & 19 & \pm & 64 & 0 & \pm & 0 & 0 & \pm & 0 & 0 & \pm & 0 \\
\hline Anisoptera & & & & & & & & & & & & & & & & & & & & & & & & & & & & & & \\
\hline Libellulidae & 83 & \pm & 96 & 111 & \pm & 164 & 37 & \pm & 111 & 99 & \pm & 103 & 222 & \pm & 255 & 833 & \pm & 1783 & 46 & \pm & 88 & 9 & \pm & 32 & 9 & \pm & 32 & 46 & \pm & 74 \\
\hline Gomphidae & 9 & \pm & 32 & 139 & \pm & 218 & 432 & \pm & 661 & 74 & \pm & 79 & 19 & \pm & 64 & 167 & \pm & 253 & 139 & \pm & 228 & 0 & \pm & 0 & 28 & \pm & 50 & 148 & \pm & 159 \\
\hline Aeshnidae & 0 & \pm & 0 & 0 & \pm & 0 & 12 & \pm & 37 & 12 & \pm & 37 & 0 & \pm & 0 & 0 & \pm & 0 & 0 & \pm & 0 & 0 & \pm & 0 & 0 & \pm & 0 & 0 & \pm & 0 \\
\hline Plecoptera & & & & & & & & & & & & & & & & & & & & & & & & & & & & & & \\
\hline Perlidae & 37 & \pm & 72 & 9 & \pm & 32 & 0 & \pm & 0 & 0 & \pm & 0 & 19 & \pm & 43 & 0 & \pm & 0 & 0 & \pm & 0 & 0 & \pm & 0 & 0 & \pm & 0 & 0 & \pm & 0 \\
\hline Hemiptera & & & & & & & & & & & & & & & & & & & & & & & & & & & & & & \\
\hline Pleidae & 0 & \pm & 0 & 9 & \pm & 32 & 160 & \pm & 324 & 0 & \pm & 0 & 0 & \pm & 0 & 0 & \pm & 0 & 0 & \pm & 0 & 0 & \pm & 0 & 0 & \pm & 0 & 0 & \pm & 0 \\
\hline Naucoridae & 56 & \pm & 130 & 102 & \pm & 198 & 37 & \pm & 111 & 0 & \pm & 0 & 65 & \pm & 88 & 0 & \pm & 0 & 9 & \pm & 32 & 9 & \pm & 32 & 0 & \pm & 0 & 9 & \pm & 32 \\
\hline Notonectidae & 0 & \pm & 0 & 0 & \pm & 0 & 0 & \pm & 0 & 12 & \pm & 37 & 0 & \pm & 0 & 9 & \pm & 32 & 0 & \pm & 0 & 9 & \pm & 32 & 0 & \pm & 0 & 0 & \pm & 0 \\
\hline Gerridae & 9 & \pm & 32 & 28 & \pm & 96 & 0 & \pm & 0 & 0 & \pm & 0 & 0 & \pm & 0 & 0 & \pm & 0 & 0 & \pm & 0 & 0 & \pm & 0 & 0 & \pm & 0 & 0 & \pm & 0 \\
\hline Veliidae & 0 & \pm & 0 & 9 & \pm & 32 & 12 & \pm & 37 & 0 & \pm & 0 & 0 & \pm & 0 & 0 & \pm & 0 & 0 & \pm & 0 & 0 & \pm & 0 & 0 & \pm & 0 & 0 & \pm & 0 \\
\hline Mesoveliidae & 0 & \pm & 0 & 0 & \pm & 0 & 0 & \pm & 0 & 0 & \pm & 0 & 0 & \pm & 0 & 0 & \pm & 0 & 0 & \pm & 0 & 0 & \pm & 0 & 0 & \pm & 0 & 0 & \pm & 0 \\
\hline Hebridae & 0 & \pm & 0 & 0 & \pm & 0 & 0 & \pm & 0 & 0 & \pm & 0 & 0 & \pm & 0 & 0 & \pm & 0 & 0 & \pm & 0 & 0 & \pm & 0 & 0 & \pm & 0 & 0 & \pm & 0 \\
\hline Corixidae & 0 & \pm & 0 & 0 & \pm & 0 & 0 & \pm & 0 & 12 & \pm & 37 & 0 & \pm & 0 & 9 & \pm & 32 & 0 & \pm & 0 & 0 & \pm & 0 & 0 & \pm & 0 & 0 & \pm & 0 \\
\hline Belostomatidae & 0 & \pm & 0 & 0 & \pm & 0 & 0 & \pm & 0 & 0 & \pm & 0 & 0 & \pm & 0 & 0 & \pm & 0 & 0 & \pm & 0 & 0 & \pm & 0 & 0 & \pm & 0 & 0 & \pm & 0 \\
\hline Megaloptera & & & & & & & & & & & & & & & & & & & & & & & & & & & & & & \\
\hline Corydalidae & 0 & \pm & 0 & 0 & \pm & 0 & 0 & \pm & 0 & 0 & \pm & 0 & 0 & \pm & 0 & 0 & \pm & 0 & 0 & \pm & 0 & 0 & \pm & 0 & 0 & \pm & 0 & 0 & \pm & 0 \\
\hline Trichoptera & & & & & & & & & & & & & & & & & & & & & & & & & & & & & & \\
\hline Hydropsychidae & 167 & \pm & 192 & 102 & \pm & 248 & 49 & \pm & 113 & 12 & \pm & 37 & 306 & \pm & 540 & 37 & \pm & 128 & 65 & \pm & 192 & 0 & \pm & 0 & 28 & \pm & 96 & 37 & \pm & 128 \\
\hline Glossosomatidae & 0 & \pm & 0 & 0 & \pm & 0 & 0 & \pm & 0 & 0 & \pm & 0 & 37 & \pm & 86 & 0 & \pm & 0 & 0 & \pm & 0 & 0 & \pm & 0 & 0 & \pm & 0 & 0 & \pm & 0 \\
\hline Leptoceridae & 28 & \pm & 50 & 28 & \pm & 96 & 99 & \pm & 130 & 12 & \pm & 37 & 46 & \pm & 74 & 37 & \pm & 72 & 37 & \pm & 72 & 0 & \pm & 0 & 28 & \pm & 50 & 37 & \pm & 99 \\
\hline Helicopsychidae & 139 & \pm & 143 & 83 & \pm & 151 & 0 & \pm & 0 & 0 & \pm & 0 & 46 & \pm & 57 & 0 & \pm & 0 & 9 & \pm & 32 & 0 & \pm & 0 & 0 & \pm & 0 & 9 & \pm & 32 \\
\hline Philopotamidae & 9 & \pm & 32 & 0 & \pm & 0 & 25 & \pm & 74 & 0 & \pm & 0 & 9 & \pm & 32 & 0 & \pm & 0 & 0 & \pm & 0 & 0 & \pm & 0 & 0 & \pm & 0 & 0 & \pm & 0 \\
\hline Odontoceidae & 0 & \pm & 0 & 0 & \pm & 0 & 62 & \pm & 113 & 0 & \pm & 0 & 19 & \pm & 64 & 0 & \pm & 0 & 9 & \pm & 32 & 0 & \pm & 0 & 0 & \pm & 0 & 0 & \pm & 0 \\
\hline Hydroptilidae & 19 & \pm & 64 & 19 & \pm & 64 & 25 & \pm & 74 & 37 & \pm & 79 & 83 & \pm & 256 & 0 & \pm & 0 & 0 & \pm & 0 & 0 & \pm & 0 & 0 & \pm & 0 & 0 & \pm & 0 \\
\hline Polycentropodidae & 0 & \pm & 0 & 19 & \pm & 64 & 49 & \pm & 98 & 62 & \pm & 148 & 9 & \pm & 32 & 102 & \pm & 174 & 0 & \pm & 0 & 0 & \pm & 0 & 28 & \pm & 96 & 0 & \pm & 0 \\
\hline Lepdoptera & & & & & & & & & & & & & & & & & & & & & & & & & & & & & & \\
\hline Pyralidae & 37 & \pm & 55 & 19 & \pm & 43 & 12 & \pm & 37 & 25 & \pm & 49 & 167 & \pm & 477 & 37 & \pm & 86 & 83 & \pm & 207 & 0 & \pm & 0 & 0 & \pm & 0 & 0 & \pm & 0 \\
\hline Orthoptera & 0 & \pm & 0 & 0 & \pm & 0 & 0 & \pm & 0 & 0 & \pm & 0 & 0 & \pm & 0 & 0 & \pm & 0 & 0 & \pm & 0 & 0 & \pm & 0 & 0 & \pm & 0 & 0 & \pm & 0 \\
\hline Coleoptera & & & & & & & & & & & & & & & & & & & & & & & & & & & & & & \\
\hline Hydrophilidae & 0 & \pm & 0 & 0 & \pm & 0 & 12 & \pm & 37 & 0 & \pm & 0 & 9 & \pm & 32 & 74 & \pm & 152 & 0 & \pm & 0 & 0 & \pm & 0 & 19 & \pm & 64 & 0 & \pm & 0 \\
\hline Elmidae & 370 & \pm & 333 & 333 & \pm & 452 & 840 & \pm & 1053 & 62 & \pm & 148 & 833 & \pm & 1324 & 796 & \pm & 1211 & 148 & \pm & 173 & 19 & \pm & 43 & 28 & \pm & 50 & 111 & \pm & 134 \\
\hline Psephenidae & 0 & \pm & 0 & 0 & \pm & 0 & 0 & \pm & 0 & 0 & \pm & 0 & 0 & \pm & 0 & 0 & \pm & 0 & 0 & \pm & 0 & 0 & \pm & 0 & 0 & \pm & 0 & 0 & \pm & 0 \\
\hline Curculionidae & 0 & \pm & 0 & 0 & \pm & 0 & 0 & \pm & 0 & 0 & \pm & 0 & 0 & \pm & 0 & 9 & \pm & 32 & 0 & \pm & 0 & 9 & \pm & 32 & 0 & \pm & 0 & 0 & \pm & 0 \\
\hline
\end{tabular}




\begin{tabular}{|c|c|c|c|c|c|c|c|c|c|c|c|c|c|c|c|c|c|c|c|c|c|c|c|c|c|c|c|c|c|c|}
\hline Taxa & \multicolumn{3}{|c|}{ P1 } & \multicolumn{3}{|c|}{$\mathrm{P} 2$} & \multicolumn{3}{|c|}{ P3 } & \multicolumn{3}{|c|}{ P4 } & \multicolumn{3}{|c|}{ P5 } & \multicolumn{2}{|c|}{ P6 } & \multicolumn{4}{|c|}{ P7 } & \multicolumn{4}{|c|}{ P8 } & \multicolumn{2}{|c|}{ P9 } & \multicolumn{3}{|c|}{ P10 } \\
\hline 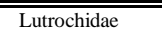 & 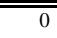 & 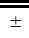 & 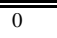 & $\overline{\overline{0}}$ & 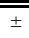 & 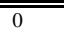 & 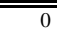 & 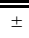 & 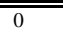 & 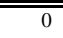 & 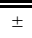 & 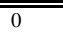 & 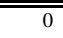 & 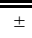 & 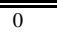 & 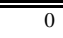 & 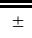 & 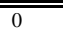 & 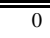 & 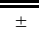 & $\overline{\overline{0}}$ & 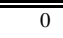 & 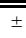 & 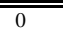 & 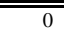 & 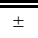 & 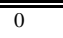 & 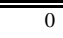 & 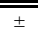 & 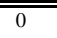 \\
\hline Scirtidae & 0 & \pm & 0 & 0 & \pm & 0 & 0 & \pm & 0 & 0 & \pm & 0 & 9 & \pm & 32 & 0 & \pm & 0 & 0 & \pm & 0 & 0 & \pm & 0 & 0 & \pm & 0 & 0 & \pm & 0 \\
\hline Gyrinidae & 0 & \pm & 0 & 0 & \pm & 0 & 0 & \pm & 0 & 0 & \pm & 0 & 0 & \pm & 0 & 0 & \pm & 0 & 0 & \pm & 0 & 0 & \pm & 0 & 0 & \pm & 0 & 0 & \pm & 0 \\
\hline Noteridae & 0 & \pm & 0 & 0 & \pm & 0 & 0 & \pm & 0 & 0 & \pm & 0 & 93 & \pm & 321 & 0 & \pm & 0 & 0 & \pm & 0 & 0 & \pm & 0 & 0 & \pm & 0 & 0 & \pm & 0 \\
\hline Dytiscidae & 9 & \pm & 32 & 0 & \pm & 0 & 12 & \pm & 37 & 0 & \pm & 0 & 9 & \pm & 32 & 19 & \pm & 43 & 0 & \pm & 0 & 9 & \pm & 32 & 0 & \pm & 0 & 0 & \pm & 0 \\
\hline \multicolumn{31}{|l|}{ Diptera } \\
\hline Chironomidae & 1139 & \pm & 1385 & 2148 & \pm & 5914 & 2877 & \pm & 3072 & 1272 & \pm & 1056 & 3944 & \pm & 9942 & 3926 & \pm & 4933 & 685 & \pm & 777 & 1556 & \pm & 3017 & 1009 & \pm & 1221 & 1361 & \pm & 1110 \\
\hline Ceratopogonidae & 56 & \pm & 101 & 296 & \pm & 957 & 12 & \pm & 37 & 12 & \pm & 37 & 176 & \pm & 446 & 176 & \pm & 278 & 9 & \pm & 32 & 19 & \pm & 64 & 222 & \pm & 364 & 46 & \pm & 74 \\
\hline Simullidae & 19 & \pm & 43 & 0 & \pm & 0 & 62 & \pm & 185 & 0 & \pm & 0 & 9 & \pm & 32 & 46 & \pm & 160 & 9 & \pm & 32 & 0 & \pm & 0 & 28 & \pm & 96 & 213 & \pm & 671 \\
\hline Empididae & 9 & \pm & 32 & 0 & \pm & 0 & 49 & \pm & 148 & 0 & \pm & 0 & 28 & \pm & 69 & 0 & \pm & 0 & 0 & \pm & 0 & 0 & \pm & 0 & 0 & \pm & 0 & 19 & \pm & 64 \\
\hline Tabanidae & 0 & \pm & 0 & 9 & \pm & 32 & 0 & \pm & 0 & 0 & \pm & 0 & 0 & \pm & 0 & 83 & \pm & 135 & 0 & \pm & 0 & 0 & \pm & 0 & 0 & \pm & 0 & 0 & \pm & 0 \\
\hline Tipulidae & 28 & \pm & 69 & 0 & \pm & 0 & 0 & \pm & 0 & 0 & \pm & 0 & 0 & \pm & 0 & 0 & \pm & 0 & 9 & \pm & 32 & 0 & \pm & 0 & 9 & \pm & 32 & 0 & \pm & 0 \\
\hline Stratiomyidae & 0 & \pm & 0 & 0 & \pm & 0 & 0 & \pm & 0 & 0 & \pm & 0 & 0 & \pm & 0 & 0 & \pm & 0 & 0 & \pm & 0 & 0 & \pm & 0 & 0 & \pm & 0 & 0 & \pm & 0 \\
\hline Muscidae & 0 & \pm & 0 & 0 & \pm & 0 & 0 & \pm & 0 & 0 & \pm & 0 & 0 & \pm & 0 & 0 & \pm & 0 & 0 & \pm & 0 & 0 & \pm & 0 & 0 & \pm & 0 & 9 & \pm & 32 \\
\hline Culicidae & 0 & \pm & 0 & 0 & \pm & 0 & 0 & \pm & 0 & 0 & \pm & 0 & 9 & \pm & 32 & 0 & \pm & 0 & 0 & \pm & 0 & 0 & \pm & 0 & 0 & \pm & 0 & 0 & \pm & 0 \\
\hline
\end{tabular}

